\title{
Manure Utilization from Cows, Goats, and Chickens as Compost, Biochar, and Poschar in Increasing the Red Chili Yield
}

\author{
Yohanes Parlindungan Situmeang ${ }^{\# 1}$, I Dewa Nyoman Sudita*, Made Suarta ${ }^{\#}$

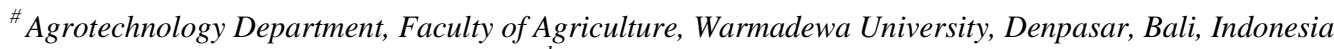 \\ E-mail: ${ }^{1}$ ypsitumeang63@gmail.com \\ *Animal Science Department, Faculty of Agriculture, Warmadewa University, Denpasar, Bali, Indonesia
}

\begin{abstract}
This study aimed to determine the characteristics of biochar, compost, and poschar from livestock manure waste and its effect on the yield of red chili plants. Randomized Block Design (RBD) with nested patterns was used in this study. The treatment composition consisted of 9 types of fertilizer (cow compost, goat compost, chicken compost, beef biochar, goat biochar, chicken biochar, beef poschar, goat poschar, and chicken poschar), and 3 levels of fertilizer doses $\left(5,10\right.$, and 15-ton ha $\left.{ }^{-1}\right)$ and one control treatment. The results showed that the type of fertilizer treatment did not significantly influence all observed variables, except the maximum plant height and fresh weight of shoot had a very significant effect. While the dose of fertilizer did not have a significant effect on most of the variables observed except for the height of the chili plant, the weight of the fresh stem and leaves, and the weight of the fresh chili harvested. In various types of fertilizer treatments, the maximum plant height obtained in chicken biochar (111.53 cm), which shows a slight difference when it was compared with the lowest plant height of $99.58 \mathrm{~cm}$ in biochar goat. The treatment of compost, biochar, and poschar sourced from 15 tons ha ${ }^{-1}$ chicken manure achieved the highest yields of fresh weight of chili harvested respectively $266.06 \mathrm{~g}, 270.95 \mathrm{~g}$, and $280.05 \mathrm{~g}$ which were significantly increased $39.16 \%, 41.72 \%$, and $46.48 \%$ compared with control (without treatments).
\end{abstract}

Keywords - biochar; compost; chili; livestock manure; poschar.

\section{INTRODUCTION}

Red chili is one of the economically valuable horticultural plants that contains protein, carbohydrates, fats, phosphorus, calcium, iron, vitamins, capsaicin, flavonoids and essential oils. The average production of red chili is 3.5 tons ha $^{-1}$. This figure is still very low when compared to its potential production of 20 tons $\mathrm{ha}^{-1}$ [1]. The main obstacle in the red chili farming is the declining soil fertility due to intensive land use without the effort to return the organic material. The reduced soil fertility has caused the soil to become nutrient-poor and crop yields have declined to a point where the land can no longer be used for agriculture. Therefore, efforts to restore soil fertility with organic matter are critical in the farming of red chili.

As a wet tropical country, Indonesia has an abundant source of organic material but has not been optimally utilized by farmers. One alternative to restore land fertility while reducing the use of chemical fertilizers is to utilize organic material derived from cow, goat, and chicken manure. This livestock manure with simple technology can be processed into compost, biochar, and poschar (the combination of compost and biochar).
Compost can improve soil fertility and agricultural output, reduce environmental pollution, land degradation, restoring land quality, and sustainable land productivity. Compost from cow, goat and chicken manure is a type of hot fertilizer which is decomposed by soil microorganisms run quickly so that the release of nutrients contained in the fertilizer can be quickly utilized for plant growth and development [2].

Biochar is a stable soil conditioner. It can last a long time in the soil, so it is good for improving soil fertility, soil quality, and soil health. Biochar from cow dung can be done only through the incomplete combustion process of manure. Biochar will be stable in soil, weather, very porous, high in carbon, and has high adsorption properties. Biochar improves soil quality by converting agricultural waste into strong soil enhancers that store carbon and make the soil more fertile [3]. Biochar treatment on agricultural land can increase $\mathrm{P}, \mathrm{K}$ content, microbial activity, and soil quality [4], [5] and can help reduce leaching of nitrogen into groundwater and reduce fertilizer costs [6], [7]. The best response to maize growth was achieved in the use of a biochar dose of 10 tons ha- 1 and a compost dose of 20 tons ha-1 [8]. The use of chicken manure by 14 tons ha- 1 can increase the fresh weight of red chili stover plants [9]. The application of biochar processing of 15 tons ha- 1 and 
fertilizer of 5 tons ha-1 had a significant effect on the number of fruits and weight of fruit harvested in red chili [10]. The use of 30-ton ha-1 compost and biochar types made from coconut shell raw materials provide the best results on the weight of fresh chili [11].

A study on compost, biochar, and poschar fertilizer from animal manure for the recovery of nutrient-poor soil fertility in red chili is still very limited. Efforts should be made to increase the production of red chili on nutrient-poor lands in Bali through improving soil fertility, especially the use of biochar and compost from various livestock manure wastes as soil amelioration. This study aims to investigate the characteristics of biochar, compost, and poschar from livestock manure and its effect on the yield of red chili plants.

\section{MATERIALS AND METHODS}

This research was conducted in a greenhouse located in the Selat Village, Abian Semal District, Badung Regency, Bali Province. The study took place from April to September 2019. The biochar was made from cow, goat, and chicken manure. It was done by charcoal in a pan made of flat drum sheets. The process of combining $100 \mathrm{~kg}$ of dry matter from cow, goat and chicken manure takes about 1-2 hours with a charcoal yield of around $30-60 \%$. Composting is done by simple fermentation using the main ingredient of animal manure $(80 \%)$, mixed with rice husk charcoal, Gamal leaves, agricultural lime, molasses, and EM4 fermenters which are subsequently incubated in the compost house to decay completely.

The study of nested patterns with randomized block designs has been applied in greenhouses. The dose factor is lodged in the type of fertilizer. Treatment factors consisted of 9 levels of fertilizers and 3 dosage levels with 1 control (without treatment) as a comparison. The treatment types of fertilizer are cow compost, goat compost, chicken compost, cow biochar, goat biochar, chicken biochar, cow poschar, goat poschar, and chicken poschar. Whereas the fertilizer dosage treatment is: 5; 10; and 15 tons ha- 1 . Based on the above design, 28 treatments were obtained. By using 3 replications, a total of 84 experimental units were obtained.
Plant parameters observed in this study included the leaf number, plant height, root wet weight, fresh weight of shoot (stem and leaf parts), number of harvested fruit, and fresh weight of harvested fruit. Laboratory analysis was also conducted to determine the characteristics of soil properties such as soil water content, soil texture, $\mathrm{pH}$, humic acid, fulvic acid, C, N, P, K, CEC, and SEM. Data obtained from this study were then processed statistically using analysis of variance. If the treatment has a significant effect, then proceed with the Duncan test of 5\% [12].

\section{RESULTS AND DISCUSSION}

\section{A. The Properties of Compost, Biochar, and Soil Prior to Research}

Soil characteristics such as neutral soil $\mathrm{pH}$, organic $\mathrm{C}$ $(2.53 \%)$ are moderate, $\mathrm{N}$ levels $(0.18 \%)$ are low, but $\mathrm{P}$ levels (31.66 ppm), K (354.93 ppm) and CEC (29.82 me/100g) are classified as high (Table 1). This nutritional status illustrates that the field requires the addition of organic matter and $\mathrm{N}$ through compost and biochar. The compost and biochar nutrition content of various animal dung used in this study shows that the $\mathrm{pH}$ (6.7-8.2) is neutral to slightly alkaline, Corganic $(12.89-29.66 \%)$ is classified as very high, $\mathrm{N}$ levels $(0.14-0.78 \%)$ are classified as low to very high, $\mathrm{P}$ content (383.09-782.62 ppm) is very high, $\mathrm{K}(159.64-368.70 \mathrm{ppm})$ is moderate to high, and CEC (16.06-21.05 me/100g) is classified as medium. Compost and biochar various livestock manure contain humic acid (0.75-2.08\%) and fulvic acid (33.49-39.78\%) relatively higher than the content of humic acid $(0.57 \%)$ and fulvic acid $(29.57 \%)$ in the research soil (Table 1).

$\mathrm{pH}, \mathrm{N}$, and $\mathrm{K}$ values look different in various types of compost and biochar. Cow compost and chicken biochar have a relatively alkaline $\mathrm{pH}$ value, while compost and biochar from goat and chicken manure are neutral. Compost from cow, goat and chicken manure successively has very high, high, and moderate $\mathrm{N}$ levels. However, biochar from cow, goat and chicken manure has low $\mathrm{N}$ levels. It can also be seen that the levels of C-organic and $\mathrm{P}$-available are very high and the CEC values are moderate in various types of compost and biochar derived from cows, goats, and chickens (Table 1).

TABLE I

Analysis Results of Soil, Compost, ANd Biochar Prior to Research*

\begin{tabular}{|c|c|c|c|c|c|c|c|c|c|c|}
\hline $\begin{array}{l}\text { Research } \\
\text { material }\end{array}$ & $\begin{array}{c}\mathrm{pH} \\
\mathrm{H}_{2} \mathrm{O} \\
\end{array}$ & $\begin{array}{c}\text { C-org } \\
(\%)\end{array}$ & $\begin{array}{c}\mathrm{N} \\
(\%) \\
\end{array}$ & $\begin{array}{c}\mathrm{P} \\
(\mathrm{ppm}) \\
\end{array}$ & $\begin{array}{c}\mathrm{K} \\
(\mathrm{ppm}) \\
\end{array}$ & $\begin{array}{c}\text { CEC } \\
(\mathrm{me} / 100 \mathrm{~g}) \\
\end{array}$ & $\mathrm{C} / \mathrm{N}$ & $\begin{array}{l}\text { HA } \\
(\%) \\
\end{array}$ & $\begin{array}{l}\text { FA } \\
(\%) \\
\end{array}$ & $\begin{array}{l}\text { WC } \\
(\%)\end{array}$ \\
\hline Soil & $6.9(\mathrm{~N})$ & $2.53(\mathrm{M})$ & $0.18(\mathrm{~L})$ & $31.66(\mathrm{H})$ & $354.93(\mathrm{H})$ & $29.82(\mathrm{H})$ & 14.06 & 0.57 & 29.57 & 6.19 \\
\hline Cow Compost & $8.2(\mathrm{SA})$ & $12.89(\mathrm{VH})$ & $0.78(\mathrm{VH})$ & $422.68(\mathrm{VH})$ & $366.80(\mathrm{H})$ & $21.05(\mathrm{M})$ & 16.53 & 0.75 & 33.49 & 14.41 \\
\hline Goat Compost & $7.5(\mathrm{~N})$ & $29.66(\mathrm{VH})$ & $0.56(\mathrm{H})$ & $746.74(\mathrm{VH})$ & $364.90(\mathrm{H})$ & $18.24(\mathrm{M})$ & 52.96 & 1.22 & 39.45 & 11.20 \\
\hline Chicken Compost & $7.4(\mathrm{~N})$ & $17.44(\mathrm{VH})$ & $0.43(\mathrm{M})$ & $782.62(\mathrm{VH})$ & $368.70(\mathrm{H})$ & $18.35(\mathrm{M})$ & 40.56 & 1.24 & 37.09 & 11.91 \\
\hline Cow Biochar & $7.5(\mathrm{~N})$ & $28.82(\mathrm{VH})$ & $0.14(\mathrm{~L})$ & $383.09(\mathrm{VH})$ & $159.64(\mathrm{M})$ & $20.50(\mathrm{M})$ & 205.86 & 1.18 & 37.17 & 5.68 \\
\hline Goat Biochar & $6.7(\mathrm{~N})$ & $22.39(\mathrm{VH})$ & $0.19(\mathrm{~L})$ & $420.62(\mathrm{VH})$ & $175.20(\mathrm{M})$ & $16.16(\mathrm{M})$ & 117.84 & 1.30 & 36.05 & 7.71 \\
\hline Chicken Biochar & 7.7 (SA) & $24.07(\mathrm{VH})$ & $0.16(\mathrm{~L})$ & $391.04(\mathrm{VH})$ & $232.36(\mathrm{H})$ & $16.06(\mathrm{M})$ & 150.44 & 2.08 & 39.78 & 6.62 \\
\hline
\end{tabular}

HA (Humic Acid), FA (Fulvic Acid), WC (Water Content), SA (slightly alkaline), N (neutral), VH (very high), H (high), M (medium), L (low) 


\section{B. The Significance of the Treatment Type and Dosage of Fertilizer.}

Table 2 shows that the treatment type of fertilizer had a significant effect $(\mathrm{P}<0.05)$ on plant height and was highly significant effect $(\mathrm{P}<0.01)$ on the weight of fresh shoot. The fertilizer dosage treatment showed a very significant effect on plant height, shoot fresh weight, and fresh weight of harvested fruit. In all the observed variables, cow compost dosage treatment only significant effect in the variable fresh roots, while the goat compost dose did not significantly affect all the variables observed. However, the chicken compost dose only has an authentic effect on the weight of fresh shoots and a real effect on the weight of fresh fruit harvested.

Biochar treatment from various animal dung, only biochar treatment from chicken manure has a very real effect on the height of the plant and fresh weight of chilies harvested. Likewise, the treatment of poschar chickens significantly affected the number of leaves, fresh weight shoot, number of fruits harvested and fresh weight of fruit harvested (Table 2). The positive effect of compost and biochar on plant growth and soil properties shows that compost is the best way to overcome the deficiency of biochar congenital nutrition, and makes it a suitable technique to improve the nutrient cycle [13].

TABLE II

SIGNIFICANCE OF THE TYPE AND DOSE OF FERTILIZER TO GROWTH VARIABLE.

\begin{tabular}{|c|c|c|c|c|c|c|}
\hline \multirow[t]{2}{*}{ Treatment } & $\begin{array}{c}\text { Plant } \\
\text { height }\end{array}$ & $\begin{array}{l}\text { Number } \\
\text { of leaves }\end{array}$ & $\begin{array}{c}\text { Fresh root } \\
\text { weight }\end{array}$ & $\begin{array}{c}\text { Fresh shoot } \\
\text { weight }\end{array}$ & $\begin{array}{c}\text { The number } \\
\text { of chilies }\end{array}$ & $\begin{array}{c}\text { Fresh weight } \\
\text { of chili }\end{array}$ \\
\hline & $(\mathrm{cm})$ & (strands) & (g) & (g) & (fruit) & (g) \\
\hline Types of Fertilizer & $*$ & n.s & n.s & $* *$ & n.s & n.s \\
\hline Dosage of Fertilizer & $* *$ & n.s & n.s & $* *$ & n.s & $* *$ \\
\hline Cow Compost & n.s & n.s & $*$ & n.s & n.s & n.s \\
\hline Goat Compost & n.s & n.s & n.s & n.s & n.s & n.s \\
\hline Chicken Compost & n.s & n.s & n.s & $* *$ & n.s & $*$ \\
\hline Cow Biochar & n.s & n.s & n.s & n.s & n.s & n.s \\
\hline Goat Biochar & n.s & n.s & n.s & n.s & n.s & n.s \\
\hline Chicken Biochar & $* *$ & n.s & n.s & n.s & n.s & $* *$ \\
\hline Cow Poschar & n.s & n.s & n.s & n.s & n.s & n.s \\
\hline Goat Poschar & n.s & n.s & n.s & n.s & n.s & n.s \\
\hline Chicken Poschar & n.s & $*$ & n.s & $*$ & $*$ & $* *$ \\
\hline
\end{tabular}

Note: **: very significant, *: significant, n.s: non-significant

\section{Effect of Type and Dosage of Compost. Biochar, and Poschar in Chili Plant}

From Table 3 it shows that the plant height obtained in the chicken biochar type is as high as $111.53 \mathrm{~cm}$, significantly different from the lowest yield obtained in the goat biochar of $99.58 \mathrm{~cm}$. The treatment of chicken biochar was also not significantly different from cow biochar, cow compost, cow poschar, and chicken poschar respectively with values of $110.92 \mathrm{~cm}, 107.29 \mathrm{~cm}, 109.46 \mathrm{~cm}$, and $105.96 \mathrm{~cm}$. However, the variable number of leaves has not shown any real effect on the various types of fertilizer applied. Fertilizer treatment showed a real effect on fresh root weight, fruit number and weight of harvested fresh chili but it has an authentic effect on fresh shoot weight (Table 2).

TABLE III.

THE EFFECT OF TYPES OF COMPOST. BIOCHAR, AND POSCHAR ON GROWTH AND YIELD OF RED CHILI

\begin{tabular}{|l|c|c|c|c|c|c|}
\hline $\begin{array}{l}\text { Treatment of } \\
\text { fertilizer types }\end{array}$ & $\begin{array}{c}\text { Height } \\
\text { of plant } \\
(\mathrm{cm})\end{array}$ & $\begin{array}{c}\text { Number } \\
\text { of leaves } \\
(\text { strands })\end{array}$ & $\begin{array}{c}\text { Fresh root } \\
\text { weight } \\
(\mathrm{g})\end{array}$ & $\begin{array}{c}\text { Fresh weight } \\
\text { of shoot } \\
(\mathrm{g})\end{array}$ & $\begin{array}{c}\text { Amount of } \\
\text { fruit harvest } \\
(\text { fruit})\end{array}$ & $\begin{array}{c}\text { Fresh weight of } \\
\text { harvested fruit } \\
(\mathrm{g})\end{array}$ \\
\hline Cow Compost & $107.29 \mathrm{ab}$ & $169.00 \mathrm{a}$ & $22.05 \mathrm{a}$ & $121.21 \mathrm{bc}$ & $27.42 \mathrm{a}$ & $220.15 \mathrm{a}$ \\
\hline Goat Compost & $100.75 \mathrm{~cd}$ & $164.58 \mathrm{a}$ & $23.14 \mathrm{a}$ & $128.71 \mathrm{abc}$ & $28.33 \mathrm{a}$ & $230.30 \mathrm{a}$ \\
\hline Chicken Compost & $102.25 \mathrm{bcd}$ & $156.42 \mathrm{a}$ & $22.02 \mathrm{a}$ & $137.49 \mathrm{a}$ & $28.83 \mathrm{a}$ & $229.75 \mathrm{a}$ \\
\hline Cow Biochar & $110.92 \mathrm{a}$ & $177.25 \mathrm{a}$ & $20.18 \mathrm{a}$ & $116.71 \mathrm{c}$ & $26.75 \mathrm{a}$ & $215.40 \mathrm{a}$ \\
\hline Goat Biochar & $99.58 \mathrm{~d}$ & $172.42 \mathrm{a}$ & $21.98 \mathrm{a}$ & $124.74 \mathrm{bc}$ & $28.08 \mathrm{a}$ & $208.62 \mathrm{a}$ \\
\hline Chicken Biochar & $111.53 \mathrm{a}$ & $167.42 \mathrm{a}$ & $21.70 \mathrm{a}$ & $125.70 \mathrm{abc}$ & $29.42 \mathrm{a}$ & $234.40 \mathrm{a}$ \\
\hline Cow Poschar & $109.46 \mathrm{a}$ & $175.92 \mathrm{a}$ & $21.00 \mathrm{a}$ & $117.29 \mathrm{c}$ & $28.42 \mathrm{a}$ & $220.46 \mathrm{a}$ \\
\hline Goat Poschar & $100.08 \mathrm{~cd}$ & $173.50 \mathrm{a}$ & $19.23 \mathrm{a}$ & $121.65 \mathrm{bc}$ & $26.08 \mathrm{a}$ & $214.49 \mathrm{a}$ \\
\hline Chicken Poschar & $105.96 \mathrm{ab}$ & $176.50 \mathrm{a}$ & $21.92 \mathrm{a}$ & $131.08 \mathrm{ab}$ & $29.50 \mathrm{a}$ & $235.47 \mathrm{a}$ \\
\hline \multicolumn{1}{|c|}{ Standard Deviation } & \pm 4.77 & \pm 6.79 & \pm 1.16 & \pm 6.72 & \pm 1.16 & \pm 9.59 \\
\hline
\end{tabular}

Note: The same letter in the same column behind the average value, was not significantly different in the Duncan $5 \%$ test. 
TABLE IV

The EFFect of Dose Of COMPost, BIochar, AND Poschar on Growth AND YiELD of Red ChILI

\begin{tabular}{|c|c|c|c|c|c|c|}
\hline $\begin{array}{c}\text { Treatment } \\
\text { Fertilizer Dose } \\
\left(\text { ton } \mathrm{ha}^{-1}\right)\end{array}$ & $\begin{array}{l}\text { High } \\
\text { plant } \\
(\mathrm{cm}) \\
\end{array}$ & $\begin{array}{l}\text { Number } \\
\text { of leaves } \\
\text { (strands) }\end{array}$ & $\begin{array}{l}\text { Weight of fresh root } \\
\qquad(\mathrm{g})\end{array}$ & $\begin{array}{c}\text { Shoot } \\
\text { fresh weight } \\
(\mathrm{g})\end{array}$ & $\begin{array}{l}\text { Number } \\
\text { of fruits } \\
\text { (fruit) }\end{array}$ & $\begin{array}{l}\text { Fresh Weight } \\
\text { harvest fruit }(\mathrm{g})\end{array}$ \\
\hline \multicolumn{7}{|l|}{ Cow Compost } \\
\hline 0 & $97.33 \mathrm{a}$ & $148.67 \mathrm{a}$ & $18.64 \mathrm{~b}$ & $114.90 \mathrm{a}$ & $25.00 \mathrm{a}$ & $191.19 \mathrm{a}$ \\
\hline 5 & $107.67 \mathrm{a}$ & $184.67 \mathrm{a}$ & $30.92 \mathrm{a}$ & $124.50 \mathrm{a}$ & $27.00 \mathrm{a}$ & $245.37 \mathrm{a}$ \\
\hline 10 & $108.50 \mathrm{a}$ & $174.33 \mathrm{a}$ & $19.76 \mathrm{~b}$ & $127.91 \mathrm{a}$ & $29.33 \mathrm{a}$ & $222.60 \mathrm{a}$ \\
\hline 15 & $115.67 \mathrm{a}$ & $168.33 \mathrm{a}$ & $18.87 \mathrm{~b}$ & $117.52 \mathrm{a}$ & $28.33 \mathrm{a}$ & $221.42 \mathrm{a}$ \\
\hline \multicolumn{7}{|l|}{ Goat Compost } \\
\hline 0 & $97.33 \mathrm{a}$ & $148.67 \mathrm{a}$ & $18.64 \mathrm{a}$ & $114.90 \mathrm{a}$ & $25.00 \mathrm{a}$ & $191.19 \mathrm{a}$ \\
\hline 5 & $106.00 \mathrm{a}$ & $182.33 \mathrm{a}$ & $24.11 \mathrm{a}$ & $125.97 \mathrm{a}$ & $29.00 \mathrm{a}$ & $233.52 \mathrm{a}$ \\
\hline 10 & $101.33 \mathrm{a}$ & $168.33 \mathrm{a}$ & $28.79 \mathrm{a}$ & $141.88 \mathrm{a}$ & $30.67 \mathrm{a}$ & $250.00 \mathrm{a}$ \\
\hline 15 & $98.33 \mathrm{a}$ & $159.00 \mathrm{a}$ & $21.00 \mathrm{a}$ & $132.10 \mathrm{a}$ & $28.67 \mathrm{a}$ & $246.50 \mathrm{a}$ \\
\hline \multicolumn{7}{|l|}{ Chicken Compost } \\
\hline 0 & $97.33 \mathrm{a}$ & $148.67 \mathrm{a}$ & $18.64 \mathrm{a}$ & $114.90 \mathrm{~b}$ & $25.00 \mathrm{a}$ & $191.19 \mathrm{~b}$ \\
\hline 5 & $99.40 \mathrm{a}$ & $157.00 \mathrm{a}$ & $21.24 \mathrm{a}$ & $135.16 \mathrm{ab}$ & $28.00 \mathrm{a}$ & $226.39 \mathrm{ab}$ \\
\hline 10 & $103.93 \mathrm{a}$ & $162.33 \mathrm{a}$ & $28.37 \mathrm{a}$ & $145.70 \mathrm{a}$ & $29.67 \mathrm{a}$ & $235.37 \mathrm{ab}$ \\
\hline 15 & $108.33 \mathrm{a}$ & $157.67 \mathrm{a}$ & $19.84 \mathrm{a}$ & $154.18 \mathrm{a}$ & $32.67 \mathrm{a}$ & $266.06 \mathrm{a}$ \\
\hline \multicolumn{7}{|l|}{ Cow Biochar } \\
\hline 0 & $97.33 \mathrm{a}$ & $148.67 \mathrm{a}$ & $18.64 \mathrm{a}$ & $114.90 \mathrm{a}$ & $25.00 \mathrm{a}$ & $191.19 \mathrm{a}$ \\
\hline 5 & $118.67 \mathrm{a}$ & $189.67 \mathrm{a}$ & $18.44 \mathrm{a}$ & $113.31 \mathrm{a}$ & $28.33 \mathrm{a}$ & $216.09 \mathrm{a}$ \\
\hline 10 & $114.33 \mathrm{a}$ & $183.67 \mathrm{a}$ & $21.39 \mathrm{a}$ & $107.13 \mathrm{a}$ & $28.00 \mathrm{a}$ & $242.73 \mathrm{a}$ \\
\hline 15 & $113.33 \mathrm{a}$ & $187.00 \mathrm{a}$ & $22.23 \mathrm{a}$ & $131.49 \mathrm{a}$ & $25.67 \mathrm{a}$ & $211.58 \mathrm{a}$ \\
\hline \multicolumn{7}{|l|}{ Goat Biochar } \\
\hline 0 & $97.33 \mathrm{a}$ & $148.67 \mathrm{a}$ & $18.64 \mathrm{a}$ & $114.90 \mathrm{a}$ & $25.00 \mathrm{a}$ & $191.19 \mathrm{a}$ \\
\hline 5 & $99.67 \mathrm{a}$ & $182.67 \mathrm{a}$ & $21.39 \mathrm{a}$ & $127.72 \mathrm{a}$ & $28.67 \mathrm{a}$ & $200.71 \mathrm{a}$ \\
\hline 10 & $99.33 \mathrm{a}$ & $177.33 \mathrm{a}$ & $25.61 \mathrm{a}$ & $135.92 \mathrm{a}$ & $29.67 \mathrm{a}$ & $235.16 \mathrm{a}$ \\
\hline 15 & $102.00 \mathrm{a}$ & $181.00 \mathrm{a}$ & $22.27 \mathrm{a}$ & $120.41 \mathrm{a}$ & $29.00 \mathrm{a}$ & $207.40 \mathrm{a}$ \\
\hline \multicolumn{7}{|l|}{ Chicken Biochar } \\
\hline 0 & $97.33 \mathrm{~b}$ & $148.67 \mathrm{a}$ & $18.64 \mathrm{a}$ & $114.90 \mathrm{a}$ & $25.00 \mathrm{a}$ & $191.19 \mathrm{c}$ \\
\hline 5 & $107.00 \mathrm{a}$ & $191.00 \mathrm{a}$ & $22.21 \mathrm{a}$ & $129.43 \mathrm{a}$ & $31.67 \mathrm{a}$ & $255.14 \mathrm{ab}$ \\
\hline 10 & $104.43 \mathrm{a}$ & $165.00 \mathrm{a}$ & $23.51 \mathrm{a}$ & $128.16 \mathrm{a}$ & $28.67 \mathrm{a}$ & $220.33 \mathrm{bc}$ \\
\hline 15 & $137.33 \mathrm{a}$ & $165.00 \mathrm{a}$ & $22.42 \mathrm{a}$ & $130.31 \mathrm{a}$ & $32.33 \mathrm{a}$ & $270.95 \mathrm{a}$ \\
\hline \multicolumn{7}{|l|}{ Cow Poschar } \\
\hline 0 & $97.33 \mathrm{a}$ & $148.67 \mathrm{a}$ & $18.64 \mathrm{a}$ & $114.90 \mathrm{a}$ & $25.00 \mathrm{a}$ & $191.19 \mathrm{a}$ \\
\hline 5 & $110.33 \mathrm{a}$ & $184.33 \mathrm{a}$ & $24.34 \mathrm{a}$ & $102.28 \mathrm{a}$ & $29.00 \mathrm{a}$ & $221.02 \mathrm{a}$ \\
\hline 10 & $115.17 \mathrm{a}$ & $180.00 \mathrm{a}$ & $23.33 \mathrm{a}$ & $129.83 \mathrm{a}$ & $28.67 \mathrm{a}$ & $235.25 \mathrm{a}$ \\
\hline 15 & $115.00 \mathrm{a}$ & $190.67 \mathrm{a}$ & $17.67 \mathrm{a}$ & $122.13 \mathrm{a}$ & $31.00 \mathrm{a}$ & $234.36 \mathrm{a}$ \\
\hline \multicolumn{7}{|l|}{ Goat Poschar } \\
\hline 0 & $97.33 \mathrm{a}$ & $148.67 \mathrm{a}$ & $18.64 \mathrm{a}$ & $114.90 \mathrm{a}$ & $25.00 \mathrm{a}$ & $191.19 \mathrm{a}$ \\
\hline 5 & $94.67 \mathrm{a}$ & $170.00 \mathrm{a}$ & $20.01 \mathrm{a}$ & $115.43 \mathrm{a}$ & $26.00 \mathrm{a}$ & $214.17 \mathrm{a}$ \\
\hline 10 & $100.33 \mathrm{a}$ & $194.67 \mathrm{a}$ & $21.08 \mathrm{a}$ & $124.79 \mathrm{a}$ & $27.67 \mathrm{a}$ & $232.14 \mathrm{a}$ \\
\hline 15 & $108.00 \mathrm{a}$ & $180.67 \mathrm{a}$ & $17.19 \mathrm{a}$ & $131.46 \mathrm{a}$ & $25.67 \mathrm{a}$ & $220.45 \mathrm{a}$ \\
\hline \multicolumn{7}{|l|}{ Chicken Poschar } \\
\hline 0 & $97.33 \mathrm{a}$ & $148.67 \mathrm{~b}$ & $18.64 \mathrm{a}$ & $114.90 \mathrm{~b}$ & $25.00 \mathrm{~b}$ & $191.19 \mathrm{c}$ \\
\hline 5 & $104.33 \mathrm{a}$ & $210.67 \mathrm{a}$ & $20.80 \mathrm{a}$ & $126.50 \mathrm{~b}$ & $32.00 \mathrm{ab}$ & $252.70 \mathrm{ab}$ \\
\hline 10 & $112.00 \mathrm{a}$ & $174.00 \mathrm{ab}$ & $28.67 \mathrm{a}$ & $134.54 \mathrm{ab}$ & $26.00 \mathrm{~b}$ & $217.96 \mathrm{bc}$ \\
\hline 15 & $110.17 \mathrm{a}$ & $172.67 \mathrm{ab}$ & $19.57 \mathrm{a}$ & $148.38 \mathrm{a}$ & $35.00 \mathrm{a}$ & $280.05 \mathrm{a}$ \\
\hline Standard Deviation & \pm 8.73 & \pm 16.74 & \pm 3.45 & \pm 11.62 & \pm 2.66 & \pm 25.31 \\
\hline
\end{tabular}

Note: The same letter in the same column behind the average value, was not significantly different in the Duncan 5\% test. 
The highest value of fresh shoot was found in chicken compost weighing $137.49 \mathrm{~g}$ which was not different from goat compost, biochar chicken, and poschar chicken, respectively with values of $128.71 \mathrm{~g}, 125.70 \mathrm{~g}$, and $131.08 \mathrm{~g}$. However, the highest fresh shoot weight in chicken compost showed significant differences in the treatment of cow compost, cow biochar, goat biochar, cow poschar, and goat poschar (Table 3).

Plant height in compost treatment and biochar dose, it was seen that only the biochar dose of chicken showed a very significant effect on the height of the chili plant (Table 2). Chicken biochar application dose of 15 tons ha ${ }^{-1}$ provides maximum plant height $(137.33 \mathrm{~cm})$, appreciably different and improved by $41.10 \%$ compared without treatment $(97.33$ $\mathrm{cm})$. However, in the variable number of leaves, none of the compost and biochar dosage treatments significantly affected (Table 4). The results of the soil analysis in the study showed humic acid $(0.57 \%)$ and fulvic acid $(29.57 \%)$ were lower compared to compost and biochar material from various livestock manure (Table 1). The increase in plant height in the biochar application of 15 tons of chicken ha-1 is thought to be caused by the content of humic acid (2.08\%) and fulvic acid $(39.78 \%)$ from biochar chicken manure which is relatively higher than other types of fertilizers. Humic acid and fulvic acid are two humic substances that represent the organic fraction of the soil. High molecular weight humic acid in the soil helps maintain soil moisture, whereas fulvic acid is a low molecular weight organic acid in the soil which can accelerate the absorption of nutrients by the roots. Humic acid and fulvic acid are essential parts of soil organic matter because they are strongly related to soil $\mathrm{C}$ and $\mathrm{N}$ [14]-[15].

The quantity and quality of organic matter is an essential consideration for managing soil fertility [16]. High levels of humic acid indicate high levels of $\mathrm{C}$, which contain free and bound $\mathrm{OH}$ phenolic groups where oxygen is the connecting bridge while the $\mathrm{COOH}$ groups are located irregularly on the aromatic ring on the structure of the humic acid functional groups. This is in line with Ref. [17], that chicken manure fertilizer gives a positive response to plant growth due to the better availability of organic materials related to $\mathrm{C}$ and $\mathrm{N}$ in the soil due to the provision of chicken manure fertilizer.

The treatment of cow compost has a significant effect on the fresh root weight, but it did not significantly affect the treatment of other fertilizer doses (Table 2). The treatment of cow manure compost in a dose of 5 tons ha $^{-1}$ gave the highest fresh root weight of $30.92 \mathrm{~g}$, an increase of $65.88 \%$ compared to without treatment, namely $18.64 \mathrm{~g}$ (Table 4).

The treatment of chicken compost and chicken poschar have significant effect on the fresh weight of the shoot. Treatment of chicken compost 15 tons $\mathrm{ha}^{-1}$ and poschar chickens 15 tons ha $^{-1}$ provides the highest value of fresh shoot at $154.18 \mathrm{~g}$ and $148.38 \mathrm{~g}$ which were significantly diverse and better by increasing $34.19 \%$ and $29.14 \%$ compared to without treatment which is $114.90 \mathrm{~g}$ (Table 4).

In the variable number of fruits, only the treatment of chicken poschar dose have a significant effect on the number of fruits (Tables 2). Poschar application of chicken manure of 15 tons $\mathrm{ha}^{-1}$ produced the highest fruit number of 35.00 fruits that were significantly different and improved $40.00 \%$ compared to those without treatment, namely 25.00 fruits (Table 4).

On observing the fresh weight of harvested fruit, it appears that the treatment of chicken compost, chicken biochar, and chicken poschar significantly affects the fresh weight of harvested fruits (Tables 2). From Figure 1, 2, and 3 it can be seen that the dosage of compost application for chicken manure 15 tons per hectare, biochar chicken 15 tons per hectare, and poschar chicken 15 tons per hectare produce the highest fresh fruit harvest weight respectively $266.06 \mathrm{~g}$, $270.95 \mathrm{~g}$, and $280.05 \mathrm{~g}$ were significantly different and more exceptional by $39.16 \%, 41.72 \%$, and $46.48 \%$, compared with no treatment, namely $191.19 \mathrm{~g}$.

The high fresh weight of harvested fruits in the treatment of chicken compost, chicken biochar, and chicken poschar at a dose of 15 tons ha $^{-1}$ is due to the raw material of chicken manure used for making compost and biochar which has a better nutrient content compared to compost and biochar derived from cow and goat dung. This is also in line with the results of chemical analysis, where the nutrient content of biochar and compost from chicken manure is higher than that of cow and goat manure (Table 1).

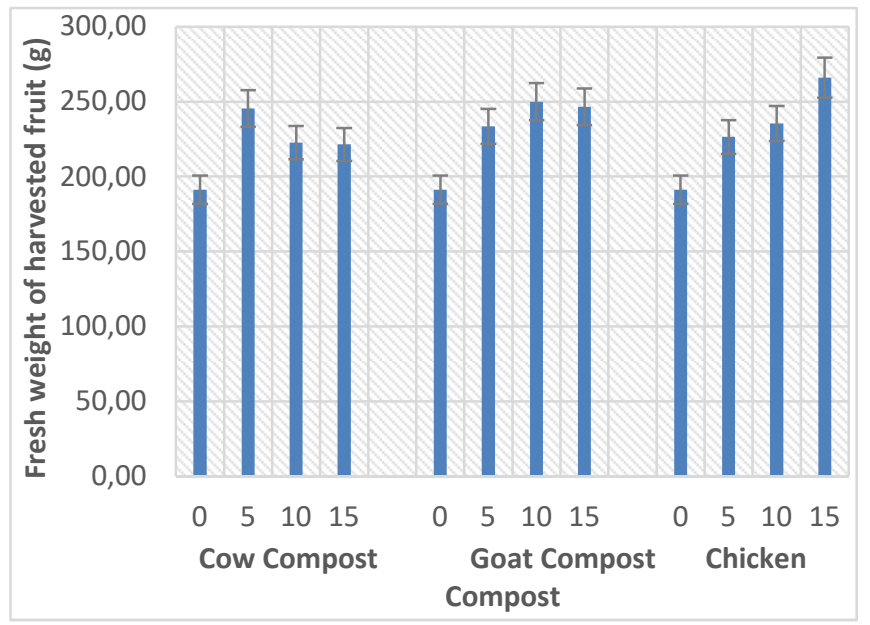

Fig. 1 Relationship between compost dose of cows, goats, and chickens with a fresh weight of fruit

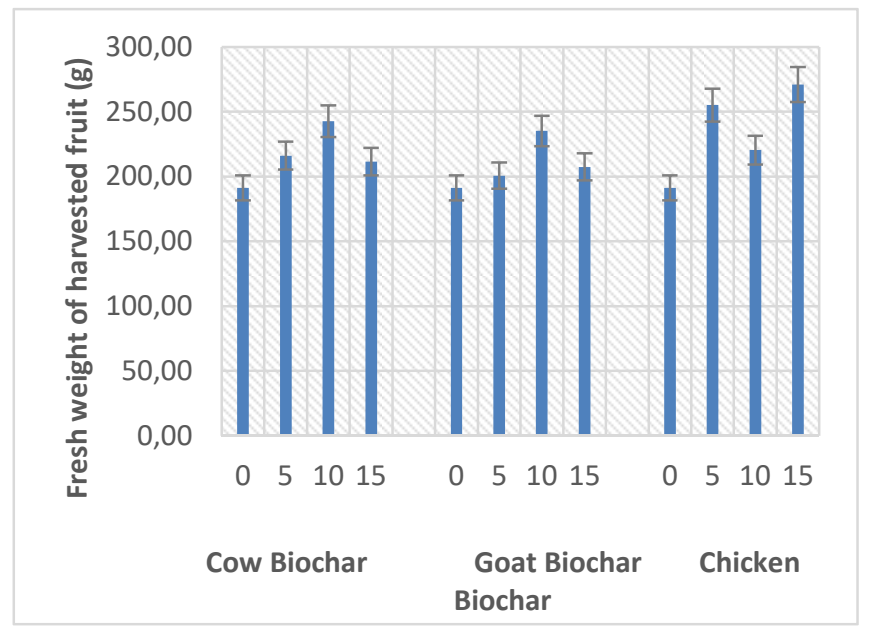

Fig. 2 Relationship between biochar doses of cows, goats, and chickens with a fresh weight of fruit 


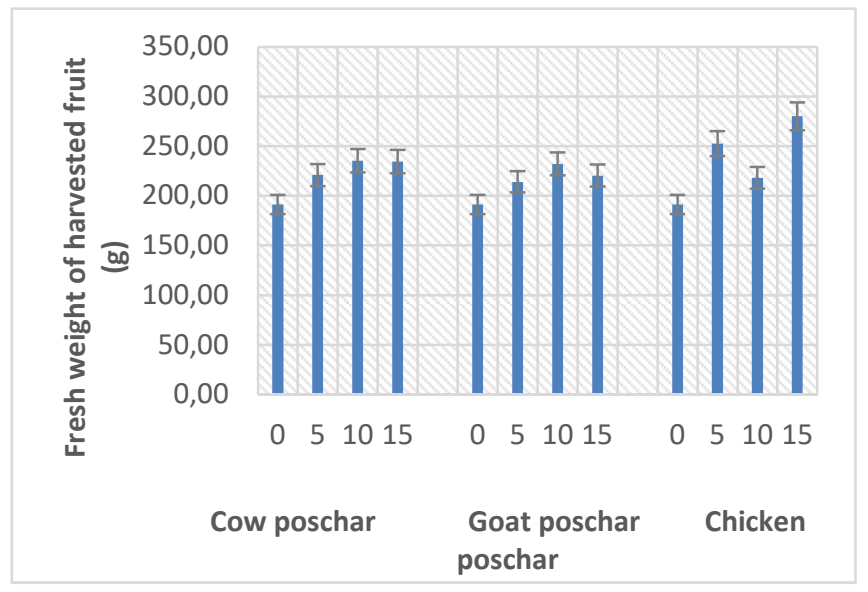

Fig. 3 Relationship between poschar dose from cows, goats, and chickens with a fresh weight of chili

Table 1 shows that the fulvic acid content (1.24\%), available $\mathrm{P}$ (782.62 ppm), and available $\mathrm{K}$ (368.70 ppm) in chicken compost were higher than cow and goat compost fertilizer. Likewise, the content of humic acid (2.08\%), fulvic acid (39.78\%), and available $\mathrm{K}$ (232.36 ppm) in biochar from chicken manure was higher than biochar from cow and goat manure. These results are in line with [18] that chicken manure gives a better effect than cow manure and goat manure in red chili plants. This difference in nutrient content is due to the type of animal and its food and the age of the animal.

Fertilizers from chicken manure contain nutrients $\mathrm{P}, \mathrm{K}$, humic acid and fluvic acid, which are relatively higher than other manure. Besides, fertilizer derived from chicken manure is also mixed with food scraps that can contribute additional nutrients to the fertilizer [19]. In addition to the high nutrient content of chicken manure, it is also able to increase the availability of phosphorus [20].

The high fresh weight of fruit harvested in the treatment of chicken compost and biochar chicken, at a dose of 15 tons $\mathrm{ha}^{-1}$ supported by the results of SEM (scanning electron microscopy) 500x magnification visible micro pore arrangement with a greater surface area in morphology or surface in compost samples, and Chicken biochar is better than compost and biochar from cows and goats (Figure 4).

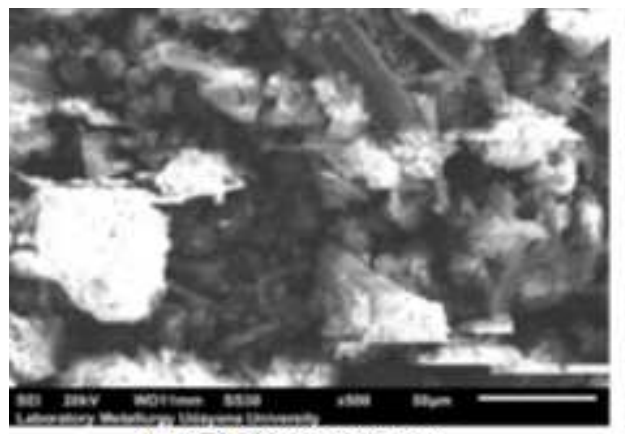

SEM of Chicken Compost

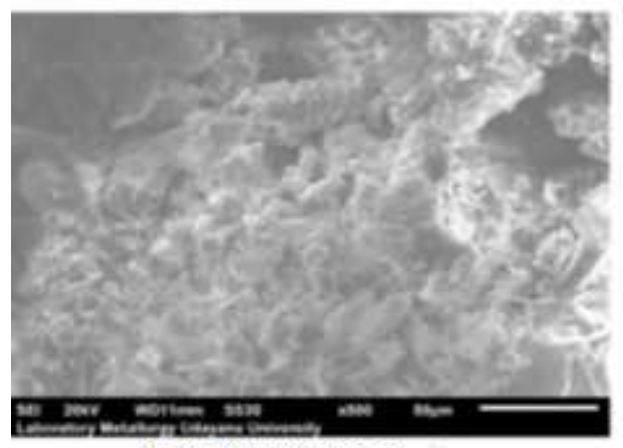

SEM of Goat Compost

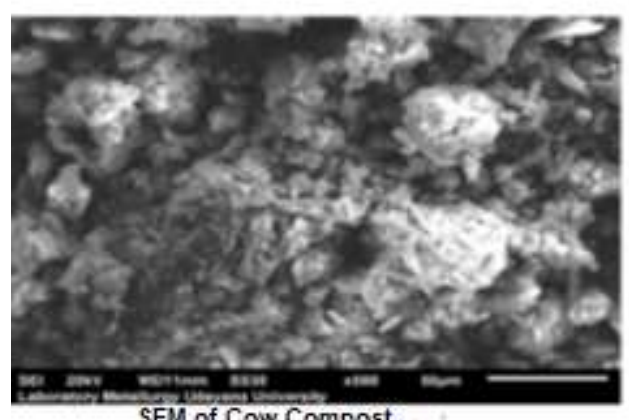

SEM of Cow Compost

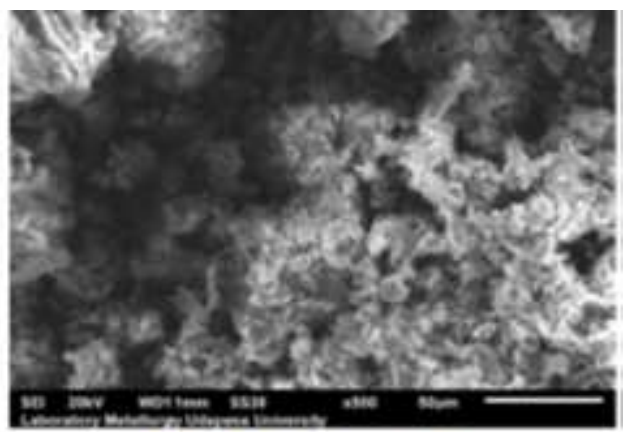

SEM of Biochar Chicken

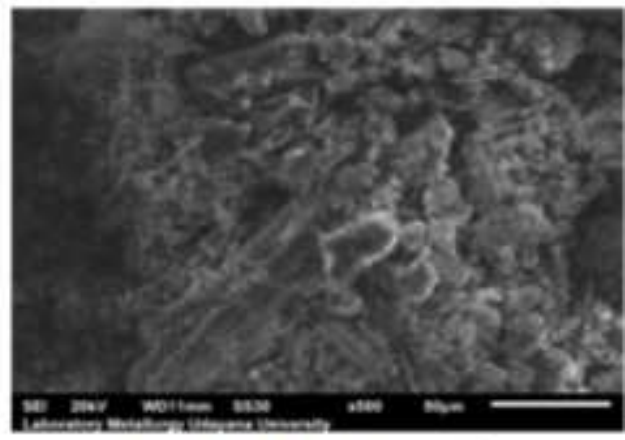

SEM of Goat Biochar

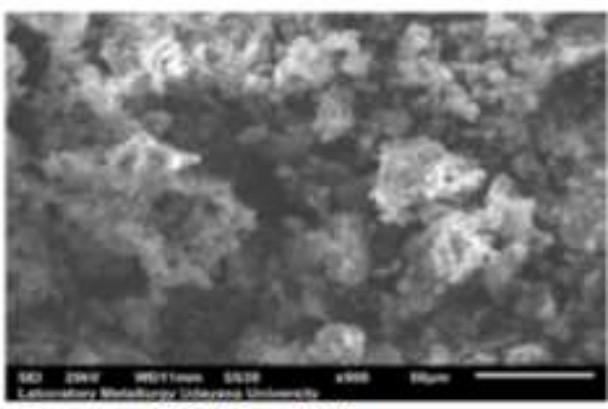

SEM of Cow Biochar

Fig. 4 Pore distribution on the surface morphology of compost and biochar from cow, goat and chicken manure with SEM analysis of 500x magnification 
Improvement of soil fertility and chili yield due to compost and biochar, supported by the physical characteristics of compost and biochar surface material from cow, goat and chicken manure at 500x magnification SEM (Figure 4). Visible morphological differences in the structure of the micropore compost and biochar are spread on the surface. The pore structure in the biochar SEM image looks better than the compost SEM. The morphology of compost and biochar on SEM biochar shows a large surface area and distribution of pores causing improved water and air systems, as well as the increased ability of the soil to absorb nutrients and water in the soil. Biochar has more stable properties, is difficult to decompose, and is able to absorb nutrients and water well compared to other organic materials, because of its greater surface area, negative surface, and density [21, 22]. Biochar which is rich in carbon is more stable and resistant to weathering in the soil so that its application to the soil does not need to be given every planting season.

The results showed that the application of compost and biochar from cow and goat manure had not significantly increased the weight of fresh fruit. However, there was a tendency for cattle compost treatment of 5 tons ha ${ }^{-1}$, biochar of cattle 10 tons $\mathrm{ha}^{-1}$, and poschar of cattle 10 tons $^{-1}$ to produce the higher fresh fruit weight of $245.37 \mathrm{~g}, 242.73 \mathrm{~g}$, and $235.25 \mathrm{~g}$ or respectively increased by $28.34 \%, 26.96 \%$, and $23.05 \%$ when compared to without treatment $191.19 \mathrm{~g}$.

Likewise, the treatment of compost, biochar, and poschar from goat manure of 10 tons $\mathrm{ha}^{-1}$ produced the highest fresh fruit weight of $250.00 \mathrm{~g}, 235.16 \mathrm{~g}$, and $232.14 \mathrm{~g}$ or each increased by $30.76 \%, 22.99 \%$, and $21.45 \%$ when compared with no treatment $191.19 \mathrm{~g}$.

The ineffectiveness of compost, biochar, and poschar treatment from cow dung and goat dung to the increase in red chili yield is thought to be caused by various types of compost and biochar originating from cows, goats, and chickens that have relatively similar $\mathrm{C}$ and $\mathrm{P}$. very high level and moderate CEC value (Table 1). The characteristics of compost and biochar from various types of manure, showing the nutritional status and physical structure of soil pores has the potential to increase soil fertility and chili yields. Therefore, to get a significant effect from compost, biochar, and poschar treatment from cow and goat manure to increase the yield of red chili, further testing is needed using a dosage level greater than 15 tons ha- 1 .

The use of a larger dose of 90 tons per hectare of cow manure gives the highest chili fruit production and significantly different from the treatment of 60 tons per hectare of goat manure, but it is not significantly different from the treatment of 36 tons per hectare of chicken manure. The highest yield in cow dung is estimated due to the slow process of decomposition of cow dung [23]. The content of organic fibers derived from plant food in livestock such as cows causes the decomposition process of organic material to proceed slowly so that the nutrients contained in cow dung can be absorbed slowly during the process of growth and development of chili plants. The results of the study of Ref. [24] showed that the application of goat manure as much as 9 tons ha $^{-1}$ gave the highest fruit weight which was significantly different compared to the lowest yield obtained in cow manure of 3 tons ha $^{-1}$.
Likewise, the use of poschar in this study, where poschar is a fertilizer composting results from compost and biochar with a balanced ratio. This poschar fertilizer has important value because compost and biochar can interact and synergize to help absorb nutrients and form topsoil, and speed up many processes that occur in the soil. Compost is more quickly decomposed by microbial activity in the soil, depending mainly on climate whereas biochar is slower to decompose microbes and is more stable in the soil, depending on the raw materials used and the environment. Charcoal has essential synergistic effects when combined with compost, making compost richer in nutrients, more biologically diverse, more moist, and more stable when applied to the soil [25]. Compost provides all nutrients and mineral salts while biochar provides moist soil conditions to retain water and all the nutrients that plants need [26]. The poschar treatment of chicken manure significantly increased the number of leaves, fresh weight of shoot, amount of fruit, and weight of fresh fruit. Meanwhile, poschar from cow and goat manure did not have a significant effect on all observed variables.

In-depth studies related to how fertilizers are made, the availability of raw materials, the methods used, and the sustainability of fertilizer production are critical. The agronomic and environmental benefits of using compost and biochar are obvious, but we need clear guidelines and standards for compost and biochar from various raw materials and methods used. According to Ref. [27], it is equally important to have a classification system for biochar that clearly shows product compositions that will meet acceptable standards.

In this study, it was found that the use of 15 tons of ha ${ }^{-1}$ compost, biochar, and poschar from chicken manure gave significant results in increasing chili yields. The findings obtained from this study, especially those relating to raw materials and methods of making and applying them to plants are expected to inspire other researchers to use livestock waste as compost and biochar to improve agricultural output in the future.

\section{CONCLUSION}

Fertilizer treatment has a highly significant effect on maximum plants and has a profound effect on the fresh weight of shoot. The dose of fertilizer has a very significant effect on plant height, fresh weight of shoot and harvested fruit. The treatment of cow compost dosage only significantly influences the root fresh weight variable, whereas the goat compost dose does not significantly affect all experimental variables. Biochar treatment from various manure, only biochar treatment from chicken manure has a very significant effect on plant height and fresh fruit weight. Likewise, the chicken poschar treatment significantly affected the number of leaves, fresh weight of shoot, amount of fruit harvested, and fresh weight of fruit harvested. Treatment of chicken compost, chicken biochar, and chicken poschar significantly affected the weight of fresh fruit. The treatment of compost, biochar, and poschar from chicken manure at a dose of 15 tons per hectare produced the highest weight of chili respectively $266.06 \mathrm{~g}, 270.95 \mathrm{~g}$, and $280.05 \mathrm{~g}$ which were significantly different or increased by $39.16 \%$, 
$41.72 \%$, and $46.48 \%$, compared without treatment that was $191.19 \mathrm{~g}$.

\section{ACKNOWLEDGMENT}

On this occasion, we extend our deepest gratitude to the Ministry of Research, Technology and Higher Education (DRPM) for their trust in funding this applied research.

\section{REFERENCES}

[1] Harpenas, A. dan Dermawan, R. 2010. Budi Daya Cabai Unggul. PT Niaga Swadaya.

[2] Prasetyo, R. 2014. Pemanfaatan berbagai sumber pupuk untuk sumber $\mathrm{N}$ dalam budidaya cabai merah (Capsicum annum L.) di tanah berpasir. Planta Tropika: Jurnal Agrosains, 2 (2), 125-132.

[3] International Biochar Initiative, 2019. Soil health: biochar use in soils. https://biochar-international.org/soil-health/

[4] Situmeang, Y.P., 2018. "Soil quality in corn cultivation using bamboo biochar, compost, and phonska." MATEC Web of Conferences. Vol. 197. EDP Sciences.

[5] Situmeang Y. P., Adnyana I M., Subadiyasa I N. N., and Merit I N. 2018. Effectiveness of bamboo biochar combined with compost and NPK fertilizer to improved soil quality and corn yield. International Journal on Advanced Science, Engineering and Information Technology, 8(5), 2241-2248.

[6] Glaser, B., Wiener, K., Seelig, S., Schmidt, H, P., Gerber., H., 2015. Biochar organic fertilizer from natural resources as substitute for mineral fertilizers. Agron.Sustainable Dev. 35, 667-678.

[7] Zhang, D., Pan, G., Wu, G., Kibue, G.W., Li, L., Zhang, X., Zheng, J., Cheng, K., Joseph, S., Liu, X., 2016. Biochar helps enhance maize productivity and reduce greenhouse gas emissions under balanced fertilization in a rainfed low fertility inceptisol. Chemosphere 142, 106-113.

[8] Situmeang, Y.P., Adnyana, I.M., Subadiyasa, I.N.N., and Merit, I.N., 2015. "Effect of dose biochar bamboo, compost, and phonska on growth of maize (Zea mays 1.) in dryland." International Journal on Advanced Science, Engineering and Information Technology 5(6): 433-439.

[9] Mariono, Supriadi, E., dan Kurnia, T.S. 2012. Pengaruh macam varietas dan dosis pupuk organik padat terhadap pertumbuhan dan hasil tanaman cabai merah (Capsicum annum L.). Jurnal Ilmiah Agrineca 7(1). http://ejournal.utp. ac.id/index.php/AFP/ article/view/8.

[10] Unangga, J.W, R., Kusnarta, IG.M., Sukartono. 2018. Aplikasi biochar, pupuk kandang, dan campuran pada bedeng permanen yang ditanami cabai merah (Capsicum annum L.). Crop Agro, Jurnal Ilmiah Agronomi, 10 (2), 148-156.

[11] Amaral, H.D.D.R., Situmeang, Y.P., \& Suarta, M. 2019. The effects of compost and biochar on the growth and yield of red chili plants. In Journal of Physics: Conference Series (Vol. 1402, No. 3, p. 033057). IOP Publishing.
[12] Hanafiah, K.A. 2012. Rancangan percobaan: teori dan aplikasi. Rajawali Pers.

[13] Schulz, H., Dunst, G., and Glaser, B., 2013. Positive effects of composted biochar on plant growth and soil fertility. Agron. Sustainable Dev. 33(4), 817-827.

[14] Stevenson, F.J. 1994. Humus Chemistry: Genesis, Composition, Reactions. 2nd ed. John Wiley \& Sons. New York.

[15] Keiji J., Teresa, H., Carlos, G., and Sanchez-Monedero, M., 2011. Influence of stability and origin of organic amendments on humification in semiarid soils. Soil Science Society of America Journal, 75 (6): 2178-2187.

[16] Cleiton H.S. and Marcus M.A. 2011. Soil organic matter fractions as indices of soil quality changes. Soil Science Society of America Journal. 75: 1766-1773.

[17] Igua, P. and Huasi, L. 2009. Effect of chicken manure, Tithonia diversifolia and albizia spp on maize plant height and dry matter production. Lessons Learn in the Eastern Highlands of PNG. 17th International Farm Management Congress, Bloomington / Normal Illinois USA.

[18] Virgundari, S., Hadi, M. S., \& Koeshendarto, K. 2013. Pengaruh Tiga Jenis Pupuk Kandang Terhadap Pertumbuhan dan Produksi Tanaman Cabai (Capssicum Annum L.) yang Dipupuk $\mathrm{KCl}$ Dengan Berbagai Dosis. Jurnal Agrotek Tropika, 1(2).

[19] Balai Besar Litbang Sumberdaya Lahan, Badan Penelitian, and Pengembangan Pertanian, 2006. Pupuk organik dan pupuk hayati. Bogor. Balai Besar Litbang Sumberdaya Lahan Pertanian.

[20] Safrianto, R., Syafruddin, S., dan Sriwati, R. 2015. Pembelian dan hasil cabai merah (Capsicum annum L) di Andisol dengan menyediakan berbagai sumber pupuk organik dan jenis endomikoriza. Jurnal Floratek, 10(2): 34-43.

[21] Lehmann, J. 2007. A handful of carbon. Nature, 447: 143-144.

[22] Hua, L., Wu, W., Liu, Y., McBride, M. B. and Chen, Y. 2009. Reduction of nitrogen loss and $\mathrm{Cu}$ and $\mathrm{Zn}$ mobility during sludge composting with bamboo charcoal amendment. Environmental Science and Pollution Research 16: 1-9.

[23] Prasetyo, R. 2014. Pemanfaatan berbagai sumber pupuk kandang sebagai sumber $\mathrm{N}$ dalam budidaya cabai merah (Capsicum annum $\mathrm{L}$.) di tanah berpasir. Planta Tropika: Jurnal Agrosains (Journal of Agro Science), 2(2), 125-132.

[24] Prananti, F. R., Sunaryo, Y., \& Darnawi, D. 2019. Pengaruh dosis pupuk bokasi kotoran kambing dan kotoran sapi terhadap hasil produksi tanaman tomat (Solanum lycopersicum 1.) Varietas new mutiara F1. Jurnal Ilmiah Agroust, 2(2), 136-144.

[25] Joseph, S.D., Camps-Arbestain, M., Lin, Y., Munroe, P., Chia, C.H., Hook, J., van Zwieten, L., Kimber, S., Cowie, A., Singh, B.P., Lehmann, J., Foidl, N., Smernik, R.J., \& Amonette, J.E. 2010. 'An investigation into the reactions of biochar in soil', Australian Journal of Soil Research 48(6-7): 501-515.

[26] Santi, L. P., \& Goenadi, D. H. 2016. Pemanfaatan bio-char sebagai pembawa mikroba untuk pemantap agregat tanah Ultisol dari Taman Bogo-Lampung E-Journal Menara Perkebunan, 78(2).

[27] Kwapinski, W., Byrne, C.M., Kryachko, E., Wolfram, P., Adley, C., Leahy, J.J., Novotny, E.H., and Hayes, M.H., 2010. Biochar from biomass and waste. Waste and Biomass Valorization, 1(2), 177-189. 